\title{
Palmitoylethanolamide Increases after Focal Cerebral Ischemia and Potentiates Microglial Cell Motility
}

\author{
Allyn Franklin, ${ }^{1}$ Sophie Parmentier-Batteur, ${ }^{3}$ Lisa Walter, ${ }^{1}$ David A. Greenberg, ${ }^{3}$ and Nephi Stella ${ }^{1,2}$ \\ Departments of ${ }^{1}$ Pharmacology and ${ }^{2}$ Psychiatry and Behavioral Sciences, University of Washington, Seattle, Washington 98195 , and ${ }^{3}$ Buck Institute for Age \\ Research, Novato, California 94945
}

Focal cerebral ischemia (FCI) induces rapid neuronal death in the ischemic core, which gradually expands toward the penumbra, partly as the result of a neuroinflammatory response. It is known that propagation of neuroinflammation involves microglial cells, the resident macrophages of the brain, which are highly motile when activated by specific signals. However, the signals that increase microglial cell motility in response to FCI remain mostly elusive.

Here, we tested the hypothesis that endocannabinoids mediate neuroinflammation propagation by increasing microglial cell motility. We found that, in mouse cerebral cortex, FCI greatly increases palmitoylethanolamide (PEA), only moderately increases anandamide [arachidonylethanolamide (AEA)], and does not affect 2-arachidonoylglycerol levels. We also found that PEA potentiates AEA-induced microglial cell migration, without affecting other steps of microglial activation, such as proliferation, particle engulfment, and nitric oxide production. This potentiation of microglial cell migration by PEA involves reduction in cAMP levels. In line with this, we provide evidence that $P E A$ acts through $\mathrm{G}_{\mathrm{i} / \mathrm{o}}$-coupled receptors. Interestingly, these receptors engaged by $P E A$ are pharmacologically distinct from $\mathrm{CB}_{1}$ and $\mathrm{CB}_{2}$ cannabinoid receptors, as well as from the WIN and abn-CBD (abnormal-cannabidiol) receptors, two recently identified cannabinoid receptors.

Our results show that PEA and AEA increase after FCI and synergistically enhance microglial cell motility. Because such a response could participate in the propagation of the FCI-induced neuroinflammation within the CNS, and because PEA is likely to act through its own receptor, a better understanding of the receptor engaged by PEA may help guide the search for improved therapies against neuroinflammation.

Key words: stroke; neuroinflammation; marijuana; lipids; nitric oxide; phagocytosis

\section{Introduction}

In the early stages of stroke, clinical symptoms reflect an impairment of function that precedes permanent structural damage (Dirnagl et al., 1999). With time, however, delayed neuroinflammation, which is likely mediated by microglial cells, contributes to cell death in the periinfarct zone, or penumbra (Dirnagl et al., 1999). Microglial cells are the first immune cells that respond to signals produced by focal cerebral ischemia (FCI) (Stoll et al., 1998). These cells reside within the brain and express membrane receptors that sense pathological changes (Kreutzberg, 1996). Engagement of receptors on microglial cells initiates a rapid, multistep change in their phenotype that is referred to as microglial cell activation (Bruce-Keller, 1999). Specifically, activated microglial cells (1) retract their processes and extend lamellipodia, allowing them to migrate (Stence et al., 2001), (2) proliferate (Hailer et al., 1999), (3) release cytotoxins and proinflammatory cytokines (Becher et al., 2000), and (4) engulf cellular debris

\footnotetext{
Received May 2, 2003; revised June 26, 2003; accepted July 1, 2003.

We are grateful to the National Institutes of Health (DA14486 to N.S. and NS39912 to D.A.G.) and the National Institute of General Medical Sciences (GM07270 to L.W.) for grant support and to Sanofi Research for providing us with SR141716A and SR144528.

Correspondence should be addressed to Dr. Nephi Stella, Department of Pharmacology, University of Washington, 1959 Northeast Pacific Street, Seattle, WA 98195-7280. E-mail: nstella@u.washington.edu. Copyright $\odot 2003$ Society for Neuroscience $\quad$ 0270-6474/03/237767-09\$15.00/0
}

(Becher et al., 2000). Pharmacological inhibition of microglial cell activation prevents neuronal damage in the penumbra (Yrjänheikki et al., 1999), indicating that this cell type constitutes a promising target for the treatment of stroke-induced damage. However, the receptors and signals that mediate microglial cell activation after FCI are not well understood.

Cannabinoids-whether plant-derived, endogenous, or synthetic - engage at least four subtypes of cannabinoid receptors: the cloned cannabinoid $\mathrm{CB}_{1}$ and $\mathrm{CB}_{2}$ receptors (Matsuda et al., 1990; Munro et al., 1993) and the as-yet-uncloned WIN and abnormal-cannabidiol (abn-CBD) receptors (the latter are also known as anandamide receptors) (Járai et al., 1999; Di Marzo et al., 2000; Breivogel et al., 2001; Hájos et al., 2001). Because cannabinoid compounds have been shown to initiate and modulate microglial cell activation (Stefano et al., 1996; Waksman et al., 1999; Walter et al., 2003), cannabinoid receptors expressed by microglial cells have been regarded as promising pharmaceutical targets (Grundy et al., 2001). $\mathrm{CB}_{1}$ and $\mathrm{CB}_{2}$ receptors are coupled to $G_{i / o}$-proteins and are normally engaged by endocannabinoids produced by neurons, astrocytes, and microglial cells (Stella and Piomelli, 2001; Walter et al., 2002, 2003). Initial characterizations of the abn-CBD receptors suggest that they also couple to $\mathrm{G}_{\mathrm{i} / \mathrm{o}^{-}}$ proteins (Mukhopadhyay et al., 2002).

Several endocannabinoids have been identified and are cate- 
gorized into two main families on the basis of their structure: the acylethanolamides (acyl-EAs), which include arachidonylethanolamide (AEA) (the prototypical endocannabinoid), and the acylesters, which include 2-arachidonoylglycerol (2-AG). AEA acts via $C_{1}$ receptors as a partial agonist and at $C_{2}$ receptors as a weak partial agonist-antagonist. 2-AG acts via both $\mathrm{CB}_{1}$ and $\mathrm{CB}_{2}$ receptors as a full agonist (Vogel et al., 1993; Stella et al., 1997; Gonsiorek et al., 2000; Sugiura et al., 2000). Multiple acylEAs with cannabinoid-like properties have been identified. For example, homo- $\gamma$-linolenoylethanolamide (HEA) and docosatetraenoylethanolamide (DEA) are two endocannabinoid candidates for $\mathrm{CB}_{1}$ receptors that have never been quantified in brain tissue (Hanus et al., 1993). Palmitoylethanolamide (PEA) has received considerable attention because of its antiinflammatory properties in peripheral tissue (Lambert et al., 2002), yet little is known about the receptor engaged by this lipid and whether it is involved in neuroinflammation. In fact, whether PEA actually belongs to the endocannabinoid lipid family is unclear, primarily because it does not bind to either $\mathrm{CB}_{1}$ or $\mathrm{CB}_{2}$ receptors (Felder et al., 1995).

Because endocannabinoid levels are dramatically increased as a result of diverse neuropathological conditions (Mechoulam et al., 2002), we sought to determine whether the amounts of endocannabinoids in mouse cerebral cortex are affected by FCI, and if so, whether these signals act on receptors that initiate and/or modulate microglial cell activation.

\section{Materials and Methods}

Materials. Acylethanolamides and deuterated acylethanolamides were synthesized in our laboratory, as described previously (Walter et al., 2002). Palmitoylisopropylamide, $R$-palmitoyl-(1-methyl)ethanolamide, $R$-palmitoyl-(2-methyl)ethanolamide, and 2-AG were from Cayman Chemical (Ann Arbor, MI). N-(piperidin-1-yl)-5-(4-chlorophenyl)-1(2,4-dichlorophenyl)-4-methyl-1H-pyrazole-3-carboxamide hydrochloride (SR141716A) and $N$-((1S)-endo-1,3,3-trimethyl-bicycloheptan-2-yl]-5-(4-chloro-3-methylphenyl)-1-(4-methylbenzyl)-pyrazole3-carboxamide) (SR144528) were a gift from Sanofi Research (Montpellier, France). abn-CBD and O-1918 were a gift from Dr. G. Kunos (National Institute on Drug Abuse and Alcoholism, Bethesda, MD).

Focal cerebral ischemia and endocannabinoid quantification. FCI was established as described previously (Parmentier-Batteur et al., 2002) after local committee review, and this was conducted according to policies on the use of animals of the Society for Neuroscience. Briefly, 15 adult male CD1 mice (25-30 gm) were separated into three groups of five mice each. In the ischemia group, the left external carotid artery was ligated, and its branches were electrocoagulated; the left common carotid artery was occluded, and a filament was introduced to occlude the left middle cerebral artery and withdrawn after $20 \mathrm{~min}$. The sham surgery group was treated similarly, except that no vessels were occluded, and the control group underwent no surgery. Mice in the ischemia and sham surgery groups were decapitated $24 \mathrm{hr}$ after surgery, and control mice were directly decapitated.

Brains were removed from the skull and placed on ice within 1 min of decapitation. Left cerebral cortices were isolated, and $6 \mathrm{~mm}$ coronal slices centered on the middle cerebral artery territory corresponding to the infarct area were dissected out and dropped directly into ice-cold $\mathrm{CHCl}_{3}$ $(20 \mathrm{ml})$. Samples were kept at $-80^{\circ} \mathrm{C}$ until endocannabinoid analysis was performed as described previously (Walter et al., 2002). Briefly, samples were brought to room temperature, and 200 pmol of deuterated standards were added. Tissue was homogenized, and endocannabinoids were extracted and purified by normal-phase HPLC (Hewlett Packard, Palo Alto, CA) and quantified by chemical ionization-gas chromatography/ mass spectrometry (CI-GC/MS) (Varian, Palo Alto, CA).

$B V-2$ cell culture. The mouse microglial cell line BV-2 [a gift from Dr. E. Blasi (University of Perugia, Perugia, Italy)] (Blasi et al., 1990) was expanded in DMEM supplemented with FBS (3\%), HEPES (10 mM),
$\mathrm{NaHCO}_{3}(5 \mathrm{~mm})$, penicillin $(100 \mathrm{U} / \mathrm{ml})$, and streptomycin $(100 \mu \mathrm{g} / \mathrm{ml})$, and passaged every $3-4 \mathrm{~d}$ for $2-12$ passages. Approximately $18 \mathrm{hr}$ before experiments, BV-2 cells were recovered at 200,000 cells/ml of MEMCellGro [MEM supplemented with 10 mм HEPES, 5 mм $\mathrm{NaHCO}_{3}, 100$ $\mathrm{U} / \mathrm{ml}$ penicillin, $100 \mu \mathrm{g} / \mathrm{ml}$ streptomycin, $2 \mathrm{~mm}$ L-glutamine, and $10 \%$ CellGro (Mediatech, Herndon, VA)]. Cells were harvested for cell migration experiments; plated onto 24 -well plates (500 $\mu \mathrm{l} /$ well) for cAMP, nitrite, and 4-[3-(4-iodophenyl)-2-(4-nitrophenyl)-2H-5-tetrazolio]1,3-benzene disulfonate sodium salt (WST-1) quantification; or plated onto $35 \mathrm{~mm}$ culture dishes ( $2 \mathrm{ml} / \mathrm{dish}$ ) for phagocytosis experiments. For all of the experiments, cannabinoids were dissolved in DMSO (at 1000×) using siliconized glass vials and siliconized pipette tips.

cAMP quantification. BV-2 cells were rinsed once with $500 \mu \mathrm{l} /$ well HEPES-bicarbonate (HB) buffer (in $\mathrm{mM}$ ): $145 \mathrm{NaCl}, 5.5 \mathrm{KCl}, 1.1 \mathrm{CaCl}_{2}$, $1.1 \mathrm{MgCl}_{2}, 3.6 \mathrm{NaHCO}_{3}, 5.5$ glucose, and 20 HEPES, pH 7.4 at $37^{\circ} \mathrm{C}$. Cells were preincubated for $10 \mathrm{~min}$ in HB buffer containing IBMX (1 mM) and incubated for $10 \mathrm{~min}$ in HB buffer containing IBMX (1 mM) and forskolin $(100 \mu \mathrm{M})$. All of the cannabinoids were added during both preincubation and incubation. To test for the involvement of $\mathrm{G}_{\mathrm{i} / \mathrm{o}}$ proteins, $\mathrm{BV}-2$ cells were pretreated with $1 \mu \mathrm{g} / \mathrm{ml}$ pertussis toxin (Calbiochem, La Jolla, CA) for $18 \mathrm{hr}$. Replacing incubation buffer with ice-cold HEPES (20 mM in water) stopped the incubation. Suspensions were sonicated, boiled for $10 \mathrm{~min}$, and centrifuged for $2 \mathrm{~min}$ at $10,000 \times g$. cAMP levels in supernatants were quantified using a radioimmunoassay Biotrak kit (Amersham Biosciences, Little Chalfont, Buckinghamshire, UK).

Cell migration. BV-2 cells $\left(5 \times 10^{4}\right.$ in $50 \mu$ l of MEM-CellGro) were added to the upper chamber and allowed to migrate through polycarbonate filters (pore size, $10 \mu \mathrm{m}$; NeuroProbe, Gaithersburg, MD) for $3 \mathrm{hr}$ at $37^{\circ} \mathrm{C}$ (humidified atmosphere of $95 \%$ air and $5 \% \mathrm{CO}_{2}$ ). Cells that did not migrate and stayed on the upper surface of the filter were wiped off, whereas cells that had migrated to the undersurface were stained with Dif-quick (IMEB, San Marcos, CA) and manually counted at $32 \times$ magnification in random fields by three scorers blinded to the experimental conditions.

Proliferation and nitrite release quantification. BV-2 cells were rinsed once with MEM-CellGro at $37^{\circ} \mathrm{C}(500 \mu \mathrm{l} /$ well $)$ and incubated in MEMCellGro containing cannabinoids and/or lipopolysaccharide (LPS) plus interferon- $\gamma($ IFN- $\gamma)($ Calbiochem, La Jolla, CA). After $18 \mathrm{hr}$, nitrites in supernatants were quantified by the Griess reaction [an index of nitric oxide (NO) production] (Granger et al., 1996), and proliferation/metabolic activity was measured with the WST-1 assay (Roche Molecular Biochemicals, Mannheim, Germany) (Tan and Berridge, 2000). Sensitivity of the Griess reaction extended to the low micromolar range of nitrite. In initial experiments, we verified that WST-1 cleavage was linear between 30 and 120 min when incubated with BV-2 cells at 200,000 cells $/ \mathrm{ml}$.

Phagocytosis of beads, fluorescence-activated cell sorter analysis, and confocal imaging. BV-2 cells were treated with cannabinoids or LPS/IFN $\gamma$. After $18 \mathrm{hr}$, medium was replaced with MEM-CellGro containing mouse IgG-opsonized fluorescent latex beads (Fluoresbrite YG carboxylate microspheres; diameter, $1 \mu \mathrm{m}$; Polysciences, Warrington, PA) at a final dilution of $\sim 100$ beads/cell, and cells were maintained for $2 \mathrm{hr}$ at $37^{\circ} \mathrm{C}$ in humidified $5 \% \mathrm{CO}_{2}-95 \%$ air. Cells were then washed twice with ice-cold PBS, detached with trypsin-EDTA $(0.05 \%-0.53 \mathrm{~mm})$, harvested, and centrifuged $(5 \mathrm{~min} ; 300 \times \mathrm{g})$. Cells were then resuspended in MEMCellGro and assayed with a Beckman Coulter (Fullerton, CA) flow cytometer such that fluorescence intensity was a measure of bead uptake. We defined the amount of phagocytosing cells as the number of events in region R1 expressed as a percentage of total events (see Fig. 4). The number of beads phagocytosed per cell was set at the geometric mean fluorescence intensity of region R1 (see Fig. 4). Z-section images were acquired with a Leica (Nussloch, Germany) TCS SP/NT confocal microscope (Keck Center, University of Washington).

\section{Results}

\section{Focal cerebral ischemia increases PEA and AEA, but not} 2-AG, in cerebral cortex

Several observations suggest that FCI should increase endocannabinoid levels in cerebral cortex: excitotoxicity and ischemia 



Figure 1. Endocannabinoid levels in cerebral cortex after focal cerebral ischemia. Mice underwent either sham surgery (Sham) or 20 min of FCI (Ischemia) or were directly decapitated (Control), as described in Materials and Methods. AEA, 2-AG, PEA, HEA, and DEA in cerebral cortex was quantified by $\mathrm{Cl}-\mathrm{GC} / \mathrm{MS}$. Values shown are the means \pm SEMs of quantities measured in $n=5$ animals per group. ${ }^{*} p<0.05$ and ${ }^{* *} p<0.01$ compared with sham (ANOVA followed by Dunnett's post-test).

induced by decapitation increase endocannabinoids in whole brain (Schmid et al., 1995; Felder et al., 1996; Kempe et al., 1996; Hansen et al., 2001; Sugiura et al., 2001), and neuronal death induced by FCI is exacerbated when $\mathrm{CB}_{1}$ receptors are either antagonized or knocked out (Nagayama et al., 1999; ParmentierBatteur et al., 2002). To determine whether FCI increases endocannabinoid levels in cerebral cortex, we used CI-GC/MS to quantify AEA, 2-AG, HEA, DEA, and PEA in cerebral cortex from control, sham-surgery, and ischemic mouse brain.

In five control animals, the levels of AEA $(50 \pm 6 \mathrm{pmol} / \mathrm{gm})$, $2-\mathrm{AG}(20 \pm 2 \mathrm{nmol} / \mathrm{gm})$, and PEA $(430 \pm 24 \mathrm{pmol} / \mathrm{gm})$ were within the range of previously reported measurements (Sugiura et al., 1996; Cadas et al., 1997; Stella et al., 1997; Di Marzo et al., 2000; Baker et al., 2001; Cravatt et al., 2001). Furthermore, we found that HEA ( $31 \pm 9 \mathrm{pmol} / \mathrm{gm})$ and DEA $(48 \pm 12 \mathrm{pmol} / \mathrm{gm})$ were as abundant as AEA, which is consistent with these two acyl-EAs being considered endocannabinoids in brain.

In a first set of experiments, we assessed the effect of sham surgery per se on the levels of endocannabinoids in cerebral cortex, because this procedure has been shown to increase the levels of signaling molecules in brain (Barnum et al., 2002). Figure 1 shows that sham surgery induced a significant increase in 2-AG $(43 \pm 4 \mathrm{nmol} / \mathrm{gm})$ and HEA $(68 \pm 8 \mathrm{pmol} / \mathrm{gm})$. Whereas amounts of AEA $(121 \pm 15 \mathrm{pmol} / \mathrm{gm})$ and DEA $(89 \pm 18 \mathrm{pmol} /$ $\mathrm{gm})$ also tended to increase, amounts of PEA ( $429 \pm 28 \mathrm{pmol} /$ gm) were not affected.

To assess the effect of FCI on endocannabinoid levels, left carotid arteries were occluded for $20 \mathrm{~min}$. Twenty-four hours after FCI, the amount of PEA in ischemic cerebral cortex increased $\sim 25$-fold compared with sham-operated animals, and DEA increased $\sim 4$-fold. The amount of AEA increased by $\sim 3$ fold compared with sham-operated animals, but this increase was not significant (Fig. 1). 2-AG levels remained unchanged compared with control (Fig. 1).

These results show that, although FCI does not increase the amount of 2-AG in cerebral cortex, it leads to a large increase in PEA and somewhat smaller increases in AEA and DEA.

\section{Microglial cells express functional $\mathrm{CB}_{1}$ and $\mathrm{CB}_{2}$ receptors}

Microglial cells express the $C_{1}$ and $C_{2}$ receptor proteins (Walter et al., 2003), suggesting that these cells can sense changes in endocannabinoid levels. $\mathrm{CB}_{1}$ and $\mathrm{CB}_{2}$ receptors couple to $\mathrm{G}_{\mathrm{i} / \mathrm{o}}$-proteins and inhibit adenylyl cyclase activity (Vogel et al., 1993; Bayewitch et al., 1995; Slipetz et al., 1995). To ascertain whether $\mathrm{CB}_{1}$ and $\mathrm{CB}_{2}$ receptors expressed by BV-2 cells inhibit adenylyl cyclase activity, we tested the effects of synthetic cannabinoid agonists on the forskolin-stimulated accumulation of cAMP. CP-55940, a bicyclic cannabinoid agonist that acts with similar potency at both $\mathrm{CB}_{1}$ and $\mathrm{CB}_{2}$ receptors (Felder et al., 1995), inhibited the forskolin response by $40 \%$ (Fig. 2a). WIN55212-2, an aminoalkylindole cannabinoid agonist that has a higher potency at $\mathrm{CB}_{2}$ than at $\mathrm{CB}_{1}$ receptors (Felder et al., 1995), inhibited the forskolin response by 47\%, whereas WIN55212-3, its inactive enantiomer, had no significant effect (Table 1). Both the $\mathrm{CB}_{1}$ receptor antagonist SR141716A (Rinaldi-Carmona et al., 1994) and the $\mathrm{CB}_{2}$ receptor antagonist SR144528 (RinaldiCarmona et al., 1998) antagonized the inhibitory effect of CP55940 on the forskolin response (Fig. 2a). Together, these results show that, in $\mathrm{BV}-2$ cells, $\mathrm{CB}_{1}$ and $\mathrm{CB}_{2}$ receptors are functionally coupled to adenylyl cyclase inhibition.

\section{PEA acts on microglial cells through $\mathrm{G}_{\mathrm{i} / \mathrm{o}}$-protein-coupled receptors}

Because the level of PEA in cerebral cortex is dramatically increased $24 \mathrm{hr}$ after FCI (Fig. 1), a time corresponding to pronounced neuroinflammation (Dirnagl et al., 1999; Iadecola and Alexander, 2001), we investigated whether microglial cells could sense this lipid. To address this question, we determined whether PEA inhibits the forskolin-stimulated accumulation of cAMP in $\mathrm{BV}-2$. We chose this approach because PEA has been shown to produce $\mathrm{CB}_{2}$-like responses (Calignano et al., 1998), and $\mathrm{CB}_{2}$ receptors are $\mathrm{G}_{\mathrm{i} / \mathrm{o}}$-protein-coupled receptors that inhibit adenylyl cyclase activity (Bayewitch et al., 1995; Slipetz et al., 1995).

Figure 2 shows that, indeed, PEA inhibited the forskolinstimulated accumulation of cAMP in BV-2 cells. This response had an $\mathrm{IC}_{50}$ of $6.4 \mathrm{nM}$ and reached a maximal $40 \%$ inhibitory effect at $1 \mu \mathrm{M}$ (Fig. 2b, Table 1). Whereas the PEA response was prevented by pertussis toxin (Fig. $2 c$ ), it was not affected by SR141716A or SR144528 (a), suggesting that PEA inhibits adenylyl cyclase activity through a mechanism independent of $\mathrm{CB}_{1}$ and $\mathrm{CB}_{2}$ receptors.

Two arguments suggest that PEA does not produce its effect by interacting with WIN receptors. Capsaicin, a vanilloid compound known to activate WIN receptors (Hájos and Freund, 2002), did not reproduce the PEA response (Table 1), and the PEA response was not antagonized by capsazepine $(3 \mu \mathrm{M})$, which antagonizes both VR1 and WIN receptors (Hájos and Freund, 2002) (Fig. 2c). Two arguments suggest that PEA does not produce its effect by interacting with abn-CBD receptors. Abnormal cannabidiol, a synthetic agonist known to activate abn-CBD re- 

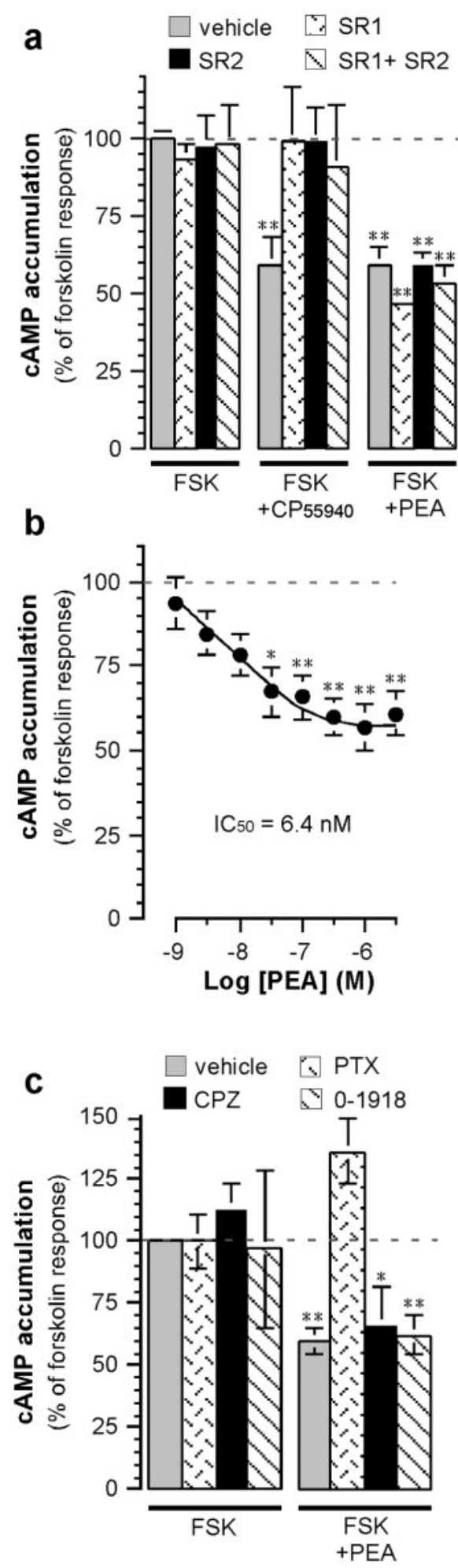

Figure 2. PEA and synthetic cannabinoids inhibit the forskolin-stimulated accumulation of CAMP in BV-2 cells. BV-2 cells were preincubated for 10 min with IBMX (1 $\mathrm{mm}$ ) and either vehicle (0.1\% DMSO), (P-55940 $(1 \mu \mathrm{M})$, or PEA $(0.3 \mu \mathrm{M})$. Cells were then incubated for an additional 10 min with the same agents plus forskolin (FSK) $(100 \mu \mathrm{M})$. During both preincubation and incubation, SR141716A (SR1) $(0.3 \mu \mathrm{M})$, SR144528 (SR2) $(0.3 \mu \mathrm{M})$, capsazepine (CPZ) $(3 \mu \mathrm{m})$, or 0-1918 $(1 \mu \mathrm{M})$ was present. To test for $\mathrm{G}_{\mathrm{i} / 0}$-protein involvement, cells were pretreated for $18 \mathrm{hr}$ with $1 \mu \mathrm{g} / \mathrm{ml}$ pertussis toxin (PTX). Results are means \pm SEMs of $9-45$ independent quantifications from 3 to 15 separate experiments performed in triplicate. ${ }^{*} p<0.05$ and ${ }^{* *} p<0.01$ compared with FSK alone (ANOVA followed by Dunnett's post-test). Basal levels of CAMP were $24.7 \pm 3.5 \mathrm{fmol} /$ well, whichincreased to $87.3 \pm 9.8 \mathrm{fmol} /$ well in the presence of FSK $(n=54)$. Horizontal dotted lines correspond to $100 \%$ forskolin response.
Table 1. Effect of synthetic cannabinoids, endocannabinoids, and analogs on forskolin-stimulated accumulation of CAMP in BV-2 cells

\begin{tabular}{lcc}
\hline Agents & Concentration & $\begin{array}{c}\text { cAMP accumulation (\% } \\
\text { of forskolin response) }\end{array}$ \\
\hline WIN55212-2 & $1 \mu \mathrm{M}$ & $53 \pm 8^{* *}$ \\
WIN55212-3 & $1 \mu \mathrm{M}$ & $111 \pm 13$ \\
AEA & $100 \mathrm{nM}$ & $100 \pm 7$ \\
2-AG & $100 \mathrm{nM}$ & $58 \pm 8^{* *}$ \\
PEA (16:0) & $300 \mathrm{nM}$ & $60 \pm 5^{* *}$ \\
Palmitic acid & $300 \mathrm{nM}$ & $103 \pm 13$ \\
Acyl-EA (14:0) & $300 \mathrm{nM}$ & $97 \pm 11$ \\
Acyl-EA (15:0) & $300 \mathrm{nM}$ & $93 \pm 8$ \\
Acyl-EA (16:1) & $300 \mathrm{nM}$ & $104 \pm 10$ \\
Acyl-EA (17:0) & $300 \mathrm{nM}$ & $81 \pm 10$ \\
Acyl-EA (18:0) & $300 \mathrm{nM}$ & $96 \pm 17$ \\
Iso-PEA & $300 \mathrm{nM}$ & $122 \pm 17$ \\
1-Meth-PEA & $300 \mathrm{nM}$ & $116 \pm 20$ \\
2-Meth-PEA & $300 \mathrm{nM}$ & $118 \pm 21$ \\
abn-CBD & $1 \mu \mathrm{MM}$ & $128 \pm 11$ \\
Capsaicin & $1 \mu \mathrm{M}$ & $91 \pm 5$ \\
\hline
\end{tabular}

cAMP accumulation was measured as described in Figure 2. Agents were as follows: WIN55212-2, WIN55212-3, anandamide, 2-AG, PEA (16:0), palmitic acid, myristylethanolamide [acyl-EA (14:0)], pentadecanoylethanolamide [acyl-EA (15:0)], palmitoleylethanolamide [acyl-EA (16:1)], margaroylethanolamide [acyl-EA (17:0)], stearoylethanolamide [acyl-EA (18:0)], palmitoylisopropylamide (iso-PEA), R-palmitoyl-(1-methyl)ethanolamide (1-methPEA), $R$-palmitoyl-(2-methyl)ethanolamide (2-meth-PEA), abn-CBD, and capsaicin. Results are expressed as percentage of the forskolin response measured within individual experiments. Values are means \pm SEMs of $9-36$ independent quantifications of cAMP (i.e., 3-12 separate experiments performed in triplicate).

${ }^{* *} p<0.01$, significantly different from forskolin response (ANOVA followed by Dunnett's post-test).

ceptors (Járai et al., 1999), did not reproduce the PEA response (Table 1), and the PEA response was not antagonized by O-1918 $(1 \mu \mathrm{M})$, an antagonist at abn-CBD receptors (Offertáler et al., 2003) (Fig. 2c).

Because PEA is effectively taken up by cells (Bisogno et al., 1997) and is a rather good substrate for fatty acid amide hydrolase (Natarajan et al., 1984), we tested whether the effect of PEA could be attributable to a metabolite formed during the 10 min preincubation plus $10 \mathrm{~min}$ incubation phase of the assay. However, palmitic acid, a product of PEA hydolysis, did not affect the forskolin-stimulated accumulation of cAMP in BV-2 cells (Table 1 ), thus ruling out the involvement of a PEA metabolite in this response.

We then assessed the structural requirements of PEA-induced inhibition. PEA contains a saturated, 16 carbon moiety (16:0) linked to ethanolamine through an amide bond. To determine whether the ability of PEA to inhibit adenylyl cyclase depends on its 16 carbon moiety, we treated BV-2 cells with the following acyl-EA analogs: myristoylethanolamide (14:0), pentadecanoylethanolamide (15:0), palmitoleoylethanolamide (16:1), margaroylethanolamide (17:0), and stearoylethanolamide (SEA) (18:0), and measured the forskolin-stimulated cAMP accumulation. Whereas margaroylethanolamide (17:0) had a nonsignificant trend to inhibit the forskolin response, none of these other analogs affected the forskolin response (Table 1). To determine whether the ability of PEA to inhibit adenylyl cyclase depends on its head group, we treated BV-2 cells with palmitoylisopropylamide, $R$-palmitoyl-(1-methyl)ethanolamide, and $R$-palmitoyl-(2methyl)ethanolamide and measured the forskolin-stimulated cAMP accumulation. None of these analogs inhibited the forskolin response (Table 1).

Together, these results show that, in BV-2 cells, PEA inhibits adenylyl cyclase activity with high potency and in a manner dependent on its precise chemical structure. The effect of PEA occurs through $\mathrm{G}_{\mathrm{i} / \mathrm{o}}$-protein-coupled receptors that are pharmacologically distinct from $\mathrm{CB}_{1}, \mathrm{CB}_{2}$, WIN, and abn-CBD receptors. 

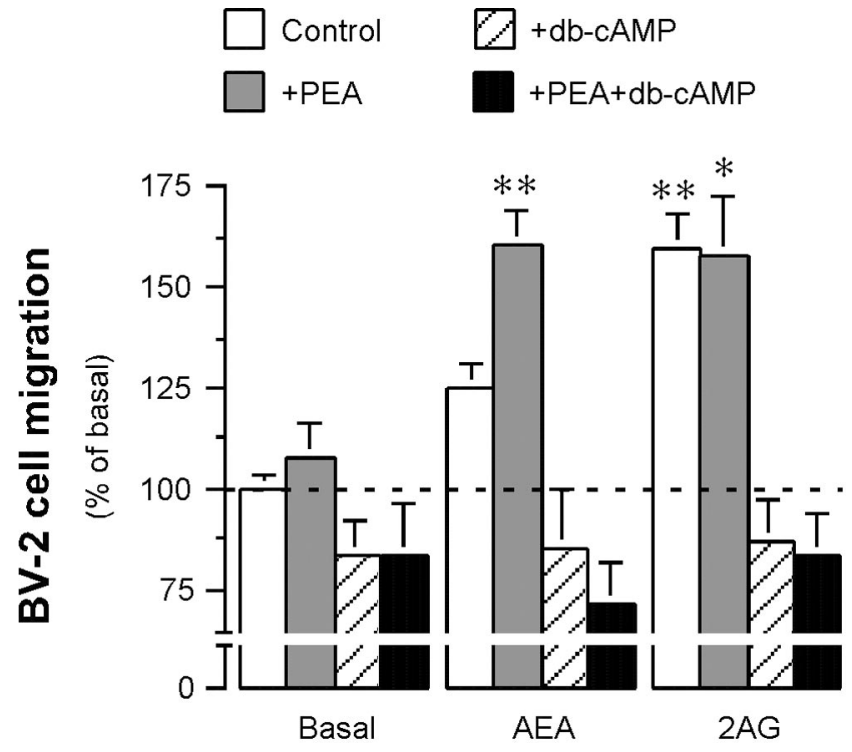

Figure 3. $P E A$ selectively potentiates the anandamide-induced $B V-2$ cell migration. Control (0.1\% DMSO), PEA (300 nM), db-CAMP (1 mm), or PEA plus db-cAMP were added to the lower compartment of the Boyden chamber in the absence (Basal) or presence of AEA ( $100 \mathrm{~nm}$ ) or 2-AG $(100 \mathrm{~nm})$. BV-2 cell migration toward these ligands was quantified, and results are expressed as a percentage of basal/control BV-2 cell migration. Results are means \pm SEMs of $9-45$ independent quantifications from 3 to 15 separate experiments performed in triplicate. ${ }^{*} p<0.05$ and ${ }^{* *} p<0.01$ compared with basal/control migration (ANOVA followed by Dunnett's posttest). The dotted horizontal line corresponds to control basal migration.

\section{PEA selectively potentiates AEA-induced microglial cell migration}

Increased microglial cell motility (i.e., one of the first steps of microglial cell activation) is essential for neuroinflammation propagation (Dirnagl et al., 1999; Yrjänheikki et al., 1999). Because PEA acts on $\mathrm{G}_{\mathrm{i} / \mathrm{o}}$-protein-coupled receptors (Fig. 2), and many $\mathrm{G}_{\mathrm{i} / \mathrm{o}}$-protein-coupled receptors, including $\mathrm{CB}_{1}$ and $\mathrm{CB}_{2}$ receptors, modulate cell motility (Derocq et al., 2000; Song and Zhong, 2000), we assessed whether PEA affects BV-2 cell motility. To address this possibility, we used the Boyden chamber assay in which BV-2 cells were added to the upper chamber and their migration through a filter toward a lower chamber containing PEA was quantified (Wilkinson, 1998). Over a range of $1 \mathrm{~nm}$ to 3 $\mu \mathrm{M}$, PEA does not affect basal BV-2 cell migration (Walter et al., 2003).

Because AEA induces BV-2 cell migration (Walter et al., 2003), and synergistic interactions between AEA and PEA have been described previously (Calignano et al., 1998), we tested whether PEA modulates AEA-induced BV-2 cell migration. PEA potentiated BV-2 cell migration induced by AEA, whereas it had no effect on BV-2 cell migration induced by $2-A G$ (Fig. 3). Note that BV-2 cell migration had not reached its ceiling point, because $2-\mathrm{AG}$ at $1 \mu \mathrm{M}$ is able to increase migration up to $225 \%$ of basal (Walter et al., 2003). Myristoylethanolamide, pentadecanoylethanolamide, palmitoleoylethanolamide, margaroylethanolamide, or SEA did not mimic the effect of PEA (data not shown).

To determine the molecular mechanism underlying the specific potentiating effect of PEA on AEA-induced migration, we assessed whether BV-2 cell migration induced by AEA and 2-AG could be mechanistically differentiated. Studies using cells transfected with cannabinoid receptors have suggested that activation of MAP kinase - rather than inhibition of adenylyl cyclase-mediates cell migration (Derocq et al., 2000; Song and Zhong, 2000). Differential involvement of MAP kinase activity could be ruled out, because both AEA and 2-AG increased MAP kinase activity to a similar extent (i.e., by approximately threefold) (data not shown) (Walter et al., 2003). Unexpectedly, BV-2 cell migration induced by PEA plus AEA, PEA plus 2-AG, and 2-AG were overridden by the addition of dibutyryl-cAMP (db-cAMP) (Fig. 3). One possibility that arises from this latter result is that inhibition of adenylyl cyclase activity is required to significantly increase BV-2 cell migration. Whereas PEA and 2-AG inhibited the forskolin-stimulated adenylyl cyclase activity to a similar extent, AEA was not effective (Table 1).

These results show that PEA potentiates BV-2 cell migration induced by AEA, without affecting the 2-AG-induced migration. The mechanism underlying this selective effect of PEA on AEA is likely attributable to the fact that increased BV-2 cell migration requires both stimulation of MAP kinase and reduced cAMP levels. Whereas 2-AG both stimulates MAP kinase and reduces cAMP levels, AEA only stimulates MAP kinase. Therefore, PEA is likely to provide the adenylyl cyclase inhibition required to increase the migration of BV-2 cells.

Endocannabinoids do not affect the ability of microglial cells to proliferate, engulf particles, and produce nitric oxide Although it is clear that microglial cell activation encompasses distinct steps (Bruce-Keller, 1999), it is unclear whether individual activating signals initiate the entire process or only specific steps of microglial cell activation. Thus, we assessed whether endocannabinoids initiate or modulate distinct steps of microglial cell activation, namely, their ability to proliferate, engulf particles, and produce nitric oxide.

To assess whether endocannabinoids or synthetic cannabinoids affect the proliferation rate of BV-2 cells, we preincubated cells with these agents and measured WST-1 conversion (Tan and Berridge, 2000). We used LPS/IFN $\gamma$ as positive controls, for these components are known to activate microglial cells (Waksman et al., 1999). Whereas LPS/IFN $\gamma$ induced a $37 \%$ increase in BV-2 cell proliferation, none of the cannabinoids affected the proliferation rate of BV-2 cells (Table 2 ).

During neuroinflammation, the ability of microglial cells to engulf particles is pivotal, because it promotes cell death (Conradt, 2002) and eliminates ensuing cellular debris (Witting et al., 2000). Because some $\mathrm{G}_{\mathrm{i} / \mathrm{o}}$-protein-coupled receptors modulate this function (Lipovsky et al., 1998), we sought to determine whether cannabinoids modulate the ability of BV-2 cells to engulf fluorescent latex beads opsonized with mouse IgG. Using fluorescence-activated cell sorter (FACS) analysis, we saw that, after $2 \mathrm{hr}, 58 \pm 5 \%$ of BV-2 cells had engulfed microspheres (Fig. $4 a, b)$, with each cell engulfing approximately eight microspheres (c). Figure 4, $d$ and $e$, shows a representative experiment in which LPS/IFN $\gamma$ increased the number of BV-2 cells that engulfed particles by $\sim 20 \%$. LPS/IFN $\gamma$ did not significantly change the number of particles engulfed by each cell (data not shown). Cannabinoids did not affect the number of BV-2 cells that engulfed beads (Table 2), nor did these agents affect the number of beads engulfed by each cell (data not shown).

Activated microglial cells often release a large amount of NO, which leads to the killing of surrounding cells (Chao et al., 1992). Cannabinoids have been reported to increase NO production from microglial cells (Stefano et al., 1996) and to decrease NO production from LPS/IFN $\gamma$-activated microglial cells (Waksman et al., 1999). We revisited this question by treating BV-2 cells with cannabinoids (either alone or in combination with LPS/IFN $\gamma$ ), and determining nitrite release after $18 \mathrm{hr}$. Cannabinoids did not 
Table 2. Cannabinoids do not affect the ability of microglial cells to proliferate, engulf particles, and release nitrites

\begin{tabular}{|c|c|c|c|c|}
\hline Agents & Concentration & $\begin{array}{l}\text { Phagocytosis (\% of } \\
\text { vehicle response) }\end{array}$ & $\begin{array}{l}\text { Nitrite production } \\
(\mu \mathrm{M})\end{array}$ & $\begin{array}{l}\text { Proliferation rate (\% of } \\
\text { vehicle response) }\end{array}$ \\
\hline Vehicle & & $100 \pm 1$ & $1.4 \pm 0.8$ & $100 \pm 1$ \\
\hline PEA & $300 \mathrm{~nm}$ & $91 \pm 5$ & $1.8 \pm 0.1$ & $103 \pm 2$ \\
\hline CP-55940 & $1 \mu \mathrm{M}$ & $102 \pm 3$ & $0.8 \pm 0.1$ & $104 \pm 2$ \\
\hline AEA & $1 \mu \mathrm{M}$ & $100 \pm 4$ & $1.0 \pm 0.1$ & $111 \pm 3$ \\
\hline $2-A G$ & $1 \mu \mathrm{M}$ & $99 \pm 2$ & $0.8 \pm 0.1$ & $110 \pm 3$ \\
\hline HEA & $1 \mu \mathrm{M}$ & $96 \pm 4$ & $1.1 \pm 0.1$ & $100 \pm 1$ \\
\hline DEA & $1 \mu \mathrm{M}$ & $94 \pm 4$ & $1.1 \pm 0.1$ & $100 \pm 1$ \\
\hline IFN- $\gamma+$ LPS & $100 \mathrm{U}+10 \mu \mathrm{g} / \mathrm{ml}$ & $119 \pm 12^{*}$ & $33.3 \pm 4.8^{* *}$ & $137 \pm 6^{*}$ \\
\hline
\end{tabular}

Cells were treated overnight with vehicle, cannabinoids, or IFN- $\gamma /$ LPS before addition of lgG-opsonized latex beads, harvesting of supernatant for nitrite quantification, and measurement of proliferation. Values are means \pm SEMs of $9-36$ independent quantifications (i.e., $3-12$ separate experiments performed in triplicate).

${ }^{*} p<0.05$ and ${ }^{* *} p<0.01$, significantly different from vehicle response (ANOVA followed by Dunnett's post-test).

affect the basal release of nitrite (Table 2), nor did they modulate the LPS/IFN $\gamma$-induced production of nitrite (data not shown).

Together, these results show that, although endocannabinoids modulate microglial cell migration (Fig. 3), they do not affect other steps of microglial cell activation, namely, their proliferation rate, particle engulfment, and NO production.

\section{Discussion}

The signals that follow FCI and mediate the propagation of neuroinflammation within the penumbra are not fully understood. Here, we show that FCI induces a large increase in PEA in cerebral cortex and a somewhat smaller increase in other acyl-EAs. We also show that PEA acts on microglial cells through $\mathrm{G}_{\mathrm{i} / \mathrm{o}}$-coupled receptors that are pharmacologically distinct from $\mathrm{CB}_{1}, \mathrm{CB}_{2}$, WIN, and abn-CBD receptors, and potentiate AEA-induced cell migration. Thus, our results suggest that PEA and AEA signal microglial cells to increase their motility and thus could contribute to the propagation of neuroinflammation in the CNS.

Traumatic brain injury increases 2-AG levels in mouse brain (Panikashvili et al., 2001; Mechoulam et al., 2002). Here, we show that FCI does not affect 2-AG levels in mouse cerebral cortex. In considering that 2-AG levels in cerebral cortex doubled in shamoperated animals, our results suggest that FCI might actually decrease $2-A G$ production. Thus, changes in endocannabinoid production appear specific to different neuropathological conditions.

Does a common biosynthetic pathway produce all of the acylEAs (Piomelli et al., 2000; Schmid et al., 2000)? Several studies show that specific physiological stimuli or pathological conditions increase the production of individual acyl-EAs (Stella et al., 1997; Giuffrida et al., 1999; Berdyshev et al., 2000; Walter et al., $2002,2003)$. We found that (1) sham surgery increases HEA production, whereas it does not affect PEA production, and (2) FCI greatly increases PEA production, whereas it does not affect HEA production (Fig. 1). Consequently, our results reinforce the notion that different biosynthetic pathways produce individual acyl-EAs. Along these lines, a recent study showed that cerebral infarction in humans also induces differential increases in acylEAs (Schäbitz et al., 2002).

To our knowledge, this is the first report describing the ability of PEA to specifically and potently inhibit adenylyl cyclase activity in cells (for negative results, see Felder et al., 1993; Ross et al., 2000). This effect does not involve $\mathrm{CB}_{1}$ and $\mathrm{CB}_{2}$ receptors, because SR141716A or SR144528 does not antagonize it. It does not involve WIN and VR1 receptors, because capsaicin does not reproduce it, nor does capsazepine antagonize it. It does not involve abn-CBD receptors, because abn-CBD does not reproduce it, nor does O-1918 antagonize it. It should be emphasized that, whereas micromolar concentrations of SR141716A antagonize WIN and abn-CBD receptors (Járai et al., 1999; Hájos et al., 2001), the PEA-induced inhibition of the forskolin-stimulated cAMP production is not affected by $300 \mathrm{~nm}$ SR141716A (Fig. 2). The effect of PEA does not occur through the binding site described for SEA, a higher PEA homolog, found in C6, because SEA did not inhibit adenylyl cyclase activity in the BV-2 cell (Table 1), and PEA does not compete SEA off its described binding site (Maccarrone et al., 2002). Through what receptors, then, does PEA inhibit adenylyl cyclase? We propose that PEA is likely to act through its own receptor. The definite proof for the existence of PEA receptors will come only from their molecular cloning. Note that our results challenge the notion that PEA is a bona fide endocannabinoid. In fact, only experiments demonstrating that PEA receptors are engaged by plant-derived cannabinoids will establish that PEA is indeed an endocannabinoid.

After FCI, is the concentration of PEA sufficient for it to activate its receptors? At this point, this question remains open, primarily because of the issue regarding the extracellular concentration reached by PEA and its compartmentalization. However, it has been shown that PEA increases to $120 \mathrm{~nm}$ in microdialysates from humans with stroke, providing supportive evidence that the extracellular concentration of PEA can achieve biologically active levels (Schäbitz et al., 2002).

We provide data that suggest a molecular mechanism underlying the specific PEA-induced potentiation of the AEA-induced microglial cell migration. Our results show that increases in BV-2 cell migration also require reduction in cAMP levels. We propose that the potentiating effect of PEA on the AEA-induced BV-2 cell migration is attributable to the ability of PEA to inhibit adenylyl cyclase activity. This is supported by the fact that $2-\mathrm{AG}$ at $100 \mathrm{~nm}$ inhibits adenylyl cyclase activity and induces migration, whereas AEA does not. In line with this, $G_{i / o}$-protein-coupled receptors increase cell migration by activating the MAP kinase pathway (Klemke et al., 1997). Interestingly, BV-2 cell migration can be further increased by simply increasing $2-A G$ concentration up to $1 \mu \mathrm{M}$ (Walter et al., 2003); however, at this concentration, 2-AG does not inhibit adenylyl cyclase, indicating that this endocannabinoid induces a bell-shaped curve inhibition of adenylyl cyclase activity and yet still strongly activates the MAP kinase pathway (data not shown) (Walter et al., 2003). The signal transduction mediating the $1 \mu \mathrm{M} 2-\mathrm{AG}$-increased BV-2 cell migration is unknown. The effect of PEA cannot be accounted for by the ability of PEA to prevent AEA metabolism, because SEA and myristoylethanolamide inhibit AEA metabolism (Jonsson et al., 2001) but do not potentiate the AEA-induced migration. The synergy described in our study is also different from that seen for 

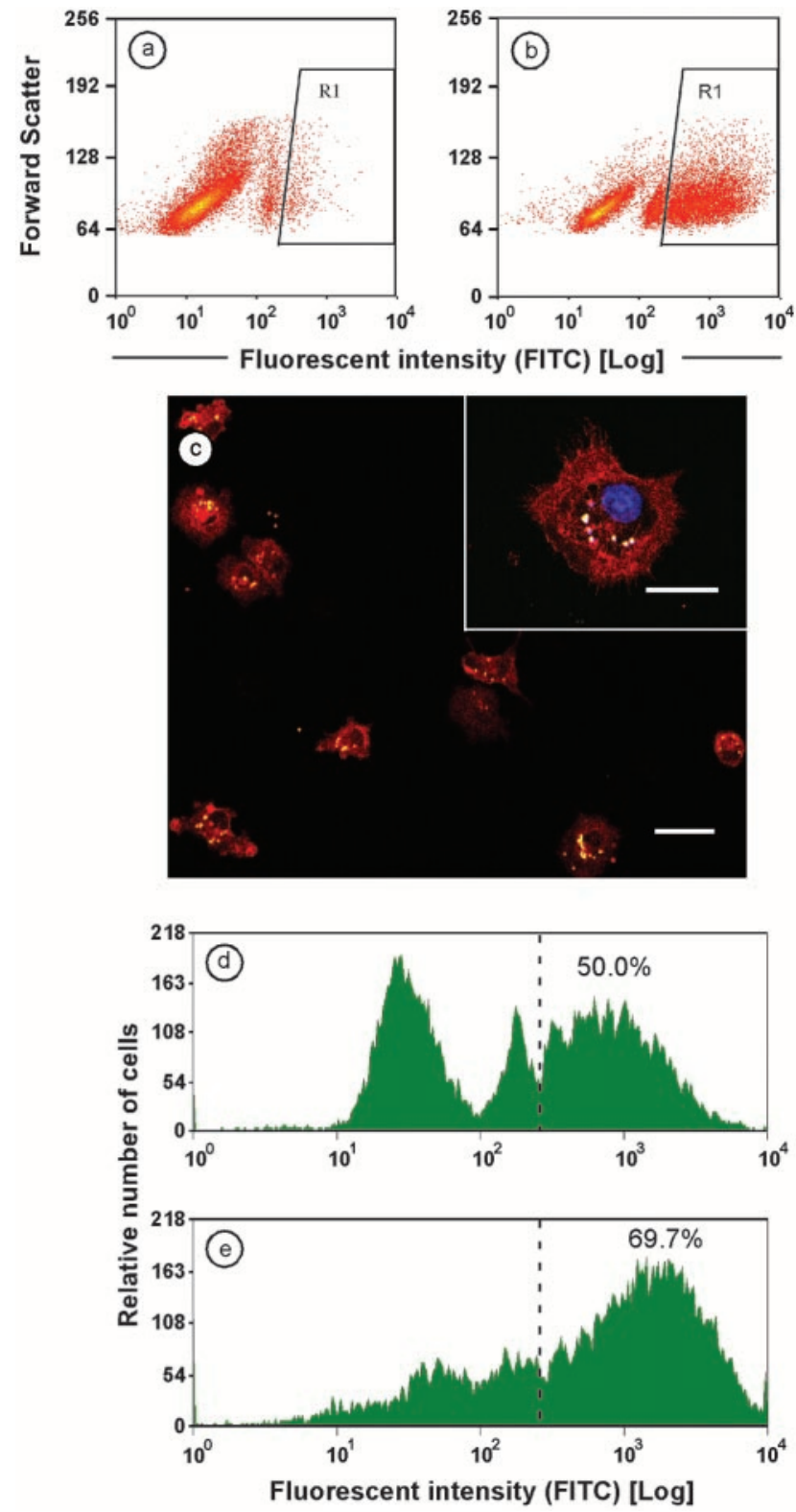

Figure 4. LPS/IFN $\gamma$ increases the ability of BV-2 cells to engulf particles. Cells were incubated with mouse lgG-opsonized beads $(1 \mu \mathrm{m})$ for $2 \mathrm{hr}$ and analyzed by FACS. Unbound beads were too small to be detected. Shown are representative dot plots of forward scatter versus fluorescence intensity for microglial cells incubated with beads at either $4^{\circ} \mathrm{C}(a)$ or $37^{\circ} \mathrm{C}(b)$. After analyzing the signal obtained at $4^{\circ} \mathrm{C}$, we discounted $>95 \%$ of the nonspecific signal by gating in R1. BV-2 cells were recovered from R1-FACS and plated onto coverslips, fixed, and labeled with phalloidin (red) to stain actin (c). Engulfed fluorescent latex beads appear yellowgreen (scale bar, $50 \mu \mathrm{m}$ ). Inset shows higher magnification of one BV-2 cell that had engulfed eight beads, which was counterstained with $4^{\prime}, 6^{\prime}$-diamidino-2-phenylindole (blue) to label the nucleus (scale bar, $20 \mu \mathrm{m}$ ). Fluorescence intensity histograms of BV-2 cells at $37^{\circ} \mathrm{C}$ pretreated for $18 \mathrm{hr}$ with either vehicle $(d)$ or IFN- $\gamma(100 \mathrm{U})$ plus LPS $(10 \mu \mathrm{g} / \mathrm{ml})(e)$ and incubated with beads for $2 \mathrm{hr}$. Also shown is the cutoff for engulfing versus nonengulfing cells (dotted line).

the effect of PEA on AEA activation of vanilloid receptors (De Petrocellis et al., 2001), because the latter is also found for SEA and other acylethanolamides (Smart et al., 2002). Furthermore, our results are also different from the study performed in cells transfected with cannabinoid receptors, because in these models, migration is not sensitive to db-cAMP (Bouaboula et al., 1995, 1996; Derocq et al., 2000; Song and Zhong, 2000).
PEA potentiates AEA-induced microglial cell migration without affecting proliferation, particle engulfment, or NO production. This result suggests that PEA receptors couple to signal transduction pathways that specifically modulate cell motility. This modality-specific initiation of microglial cell activation by endocannabinoids contradicts the notion that all of the activating stimuli lead to the same, stereotypical pattern of microglial cell activation.

In summary, we show that PEA and AEA amounts increase after FCI, which possibly signal microglial cells to increase their mobility. Increase in AEA levels may also in turn act on (1) presynaptic $\mathrm{CB}_{1}$ receptors to reduce excessive release of glutamate and allied excitotoxicity (Shen et al., 1996) and (2) $\mathrm{CB}_{1}$ receptors expressed by blood vessels to enhance cerebral blood flow (Parmentier-Batteur et al., 2002). We propose that the molecular identification of PEA receptors and a better understanding of their pharmacology should help in developing therapies against the propagation of neuroinflammation, possibly without altering the beneficial effects produced by endocannabinoids that act on $\mathrm{CB}_{1}$ receptors.

\section{References}

Baker D, Pryce G, Croxford LJ, Brown P, Pertwee RG, Makriyannis A, Knanolkar A, Layward L, Fezza F, Bisogno T, DiMarzo V (2001) Endocannabinoids control spasticity in a multiple sclerosis model. FASEB J 15:300-302.

Barnum SR, Ames RS, Maycox PR, Hadingham SJ, Meakin J, Harrison D, Parsons AA (2002) Expression of the complement C3a and C5a receptors after permanent focal ischemia: an alternative interpretation. Glia 38:169-173.

Bayewitch M, Avidor-Reiss T, Levy R, Barg J, Mechoulam R, Vogel Z (1995) The peripheral cannabinoid receptor: adenylate cyclase inhibition and $G$ protein coupling. FEBS Lett 375:143-147.

Becher B, Prat A, Antel JP (2000) Brain-immune connection: immunoregulatory properties of CNS-resident cells. Glia 29:293-304.

Berdyshev EV, Schmid PC, Dong Z, Schmid HHO (2000) Stress-induced generation of $\mathrm{N}$-acylethanolamines in mouse epidermal JB6 $\mathrm{P}^{+}$cells. Biochem J 346:369-374.

Bisogno T, Maurelli S, Melck D, De Petrocellis L, Di Marzo V (1997) Biosynthesis, uptake, and degradation of anandamide and palmitoylethanolamide in leukocytes. J Biol Chem 272:3315-3323.

Blasi E, Barluzzi R, Bocchini V, Mazzolla R, Bistoni F (1990) Immortalization of murine microglial cells by a v-raf/v-myc carrying retrovirus. J Neuroimmunol 27:229-237.

Bouaboula M, Poinot-Chazel C, Bourrié B, Canat X, Calandra B, RinaldiCarmona M, Le Fur G, Casellas P (1995) Activation of mitogenactivated protein kinase by stimulation of the central cannabinoid receptor CB1. Biochem J 312:637-641.

Bouaboula M, Poinot-Chazel C, Marchand J, Canat X, Bourrié B, RinaldiCarmona M, Calandra B, Le Fur G, Casellas P (1996) Signaling pathway associated with stimulation of CB2 peripheral cannabinoid receptor. Eur J Biochem 237:704-711.

Breivogel CS, Griffin G, Di Marzo V, Martin BR (2001) Evidence for a new $G$ protein-coupled cannabinoid receptor in mouse brain. Mol Pharmacol 60:155-163.

Bruce-Keller AJ (1999) Microglial-neuronal interactions in synaptic damage and recovery. J Neurosci Res 58:191-201.

Cadas H, di Tomaso E, Piomelli D (1997) Occurrence and biosynthesis of endogenous cannabinoid precursor, $N$-arachidonoyl phosphatidylethanolamine, in rat brain. J Neurosci 17:1226-1242.

Calignano A, La Rana G, Giuffrida A, Piomelli D (1998) Control of pain initiation by endogenous cannabinoids. Nature 394:277-281.

Chao CC, Hu S, Molitor TW, Shaskan EG, Peterson PK (1992) Activated microglia mediate neuronal cell injury via a nitric oxide mechanism. J Immunol 149:2736-2741.

Conradt B (2002) With a little help from your friends: cells don't die alone. Nat Cell Biol 4:E139.

Cravatt BJ, Demarest K, Patricelli M, Bracey MH, Giang DK, Martin BR, Lichtman AH (2001) Supersensitivity to anandamide and enhanced en- 
dogenous cannabinoid signaling in mice lacking fatty acid amide hydrolase. Proc Natl Acad Sci USA 98:9371-9376.

De Petrocellis L, Davis JB, Di Marzo V (2001) Palmitoylethanolamide enhances anandamide stimulation of human vanilloid VR1 receptors. FEBS Lett 506:253-256.

Derocq J-M, Jbilo O, Bouaboula M, Ségui M, Clère C, Casellas P (2000) Genomic and functional changes induced by the activation of the peripheral cannabinoid receptor CB2 in the promyelocytic cells HL-60. J Biol Chem 275:15621-15628.

Di Marzo V, Breivogel CS, Tao Q, Bridgen DT, Razdan RK, Zimmer AM, Zimmer A, Martin BR (2000) Levels, metabolism, and pharmacological activity of anandamide in CB1 cannabinoid receptor knockout mice: evidence for non-CB1, non-CB2 receptor-mediated actions of anandamide in mouse brain. J Neurochem 75:2434-2444.

Dirnagl U, Iadecola C, Moskowitz MA (1999) Pathobiology of ischaemic stroke: an integrated view. Trends Neurosci 22:391-397.

Felder CC, Briley EM, Axelrod J, Simpson JT, Mackie K, Devane WA (1993) Anandamide, an endogenous cannabimimetic eicosanoid, binds to the cloned human cannabinoid receptor and stimulates receptor-mediated signal transduction. Proc Natl Acad Sci USA 90:7656-7660.

Felder CC, Joyce KE, Briley EM, Mansouri J, Mackie K, Blond O, Lai Y, Ma AL, Mitchell RL (1995) Comparison of the pharmacology and signal transduction of the human cannabinoid $\mathrm{CB} 1$ and $\mathrm{CB} 2$ receptors. Mol Pharmacol 48:443-450.

Felder CC, Nielsen A, Briley EM, Palkovits M, Priller J, Axelrod J, Nguyen DN, Richardson JM, Riggin RM, Koppel GA, Paul SM, Becker GW (1996) Isolation and measurement of the endogenous cannabinoid receptor agonist, anandamide, in brain and peripheral tissues of human and rat. FEBS Lett 393:231-235.

Giuffrida A, Parsons LH, Kerr TM, Rodríguez de Fonseca F, Navarro M, Piomelli D (1999) Dopamine activation of endogenous cannabinoid signalling in dorsal striatum. Nat Neurosci 2:358-363.

Gonsiorek W, Lunn C, Fan X, Narula S, Lundell D, Hipkin RW (2000) Endocannabinoid 2-arachidonyl glycerol is a full agonist through human type 2 cannabinoid receptor: antagonism by anandamide. Mol Pharmacol 57:1045-1050.

Granger DL, Taintor RR, Boockvar KS, Hibbs JB (1996) Measurement of nitrate and nitrite in biological samples using nitrate reductase and Griess reaction. Methods Enzymol 268:142-152.

Grundy RI, Rabuffetti M, Beltramo M (2001) Cannabinoids and neuroprotection. Mol Neurobiol 24:29-52.

Hailer NP, Grampp A, Nitsch R (1999) Proliferation of microglia and astrocytes in the dentate gyrus following entorhinal cortex lesion: a quantitative bromodeoxyuridine-labelling study. Eur J Neurosci 11:3359-3364.

Hájos N, Freund TF (2002) Pharmacological separation of cannabinoid sensitive receptors on hippocampal excitatory and inhibitory fibers. Neuropharmacology 43:503-510.

Hájos N, Ledent C, Freund TF (2001) Novel cannabinoid-sensitive receptor mediates inhibition of glutamatergic synaptic transmission in the hippocampus. Neuroscience 106:1-4.

Hansen HH, Schmid PC, Bittigau P, Lastres-Becker I, Berrendero F, Manzanares J, Ikonomidou C, Schmid HHO, Fernández-Ruiz, Hansen H (2001) Anandamide, but not 2-arachidonoylglycerol, accumulates during in vivo neurodegeneration. J Neurochem 78:1415-1427.

Hanus L, Gopher A, Almog S, Mechoulam R (1993) Two new unsaturated fatty acid ethanolamides in brain that bind to the cannabinoid receptor. J Med Chem 36:3032-3034.

Iadecola C, Alexander M (2001) Cerebral ischemia and inflammation. Curr Opin Neurol 14:89-94.

Járai Z, Wagner JA, Varga K, Lake KD, Compton DR, Martin BR, Zimmer AM, Bonner TI, Buckley NE, Mezey E, Razdan RK, Zimmer A, Kunos G (1999) Cannabinoid-induced mesenteric vasodilation through an endothelial site distinct from CB1 or CB2 receptors. Proc Natl Acad Sci USA 96:14136-14141.

Jonsson K-O, Vandevoorde S, Lambert DM, Tiger G, Fowler CJ (2001) Effects of homologues and analogues of palmitoylethanolamide upon the inactivation of the endocannabinoid anandamide. Br J Pharmacol 133:1263-1275.

Kempe K, Hsu F-F, Bohrer A, Turk J (1996) Isotope dilution mass spectrometric measurements indicate that arachidonylethanolamide, the proposed endogenous ligand of the cannabinoid receptor, accumulates in rat brain tissue post mortem but is contained at low levels in or is absent from fresh tissue. J Biol Chem 271:17287-17295.

Klemke RL, Cai S, Giannini AL, Gallagher PJ, de Lanerolle P, Cheresh DA (1997) Regulation of cell motility by mitogen-activated protein kinase. J Cell Biol 137:481-492.

Kreutzberg GW (1996) Microglia: a sensor for pathological events in the CNS. Trends Neurosci 19:312-318.

Lambert DM, Vandevoorde S, Jonsson K-O, Fowler CJ (2002) The palmitoylethanolamide family: a new class of anti-inflammatory agents? Curr Med Chem 9:663-674.

Lipovsky MM, Gekker G, Hu S, Hoepelman AIM, Peterson PK (1998) Morphine enhances complement receptor-mediated phagocytosis of Cryptococcus neoformans by human microglia. Clin Immunol Immunopathol 87:163-167.

Maccarrone M, Pauselli R, Di Rienzo M, Finazzi-Agrò A (2002) Binding, degradation and apoptotic activity of stearoylethanolamide in rat C6 glioma cells. Biochem J 366:137-144.

Matsuda LA, Lolait SJ, Brownstein MJ, Young AC, Bonner TI (1990) Structure of a cannabinoid receptor and functional expression of the cloned cDNA. Nature 346:561-564.

Mechoulam R, Spatz M, Shohami E (2002) Endocannabinoids and neuroprotection. Sci STKE 129:1-6.

Mukhopadhyay S, Chapnick BM, Howlett AC (2002) Anandamideinduced vasorelaxation in rabbit aortic rings has two components: G protein dependent and independent. Am J Physiol 282:H2046-H2054.

Munro S, Thomas KL, Abu-Shaar M (1993) Molecular characterization of a peripheral receptor for cannabinoids. Nature 365:61-65.

Nagayama T, Sinor AD, Simon RP, Chen J, Graham SH, Jin K, Greenberg DA (1999) Cannabinoids and neuroprotection in global and focal cerebral ischemia and in neuronal cultures. J Neurosci 19:2987-2995.

Natarajan V, Schmid PC, Reddy PV, Schmid HHO (1984) Catabolism of $\mathrm{N}$-acylethanolamine phospholipids by dog brain preparations. J Neurochem 42:1613-1619.

Offertáler L, Mo F, Bátkai S, Liu J, Begg M, Razdan RK, Martin BR, Bukoski $R D$, Kunos G (2003) Selective ligands and cellular effectors of a $G$ protein-coupled endothelial cannabinoid receptor. Mol Pharmacol 63:699-705.

Panikashvili D, Simeonidou C, Ben-Shabat S, Hanus L, Breuer A, Mechoulam $\mathrm{R}$, Shohami E (2001) An endogenous cannabinoid (2-AG) is neuroprotective after brain injury. Nature 413:527-531.

Parmentier-Batteur S, Jin K, Ou Mao X, Xie L, Greenberg DA (2002) Increased severity of stroke in CB1 cannabinoid receptor knock-out mice. J Neurosci 22:9771-9775.

Piomelli D, Giuffrida A, Calignano A, Rodriguez de Fonseca F (2000) The endocannabinoid system as a target for therapeutic drugs. Trends Pharmacol 21:218-224.

Rinaldi-Carmona M, Barth F, Héaulme M, Shire D, Calandra B, Congy C, Martinez S, Maruani J, Néliat G, Caput D, Ferrara P, Soubrié P, Brelière JC, Le Fur G (1994) SR141716A, a potent and selective antagonist of the brain cannabinoid receptor. FEBS Lett 350:240-244.

Rinaldi-Carmona M, Barth F, Millan J, Derocq J-M, Casellas P, Congy C, Oustric D, Sarran M, Bouaboula M, Calandra B, Portier M, Shire D, Brelière J-C, Le Fur G (1998) SR 144528, the first potent and selective antagonist of the CB2 cannabinoid receptor. J Pharmacol Exp Ther 284:644-650.

Ross RA, Brockie HC, Pertwee RG (2000) Inhibition of nitric oxide production in RAW264.7 macrophages by cannabinoids and palmitoylethanolamide. Eur J Pharmacol 401:121-130.

Schäbitz W-R, Giuffrida A, Berger C, Aschoff A, Schwaninger M, Schwab S, Piomelli D (2002) Release of fatty acid amides in a patient with hemispheric stroke. Stroke 33:2112-2114.

Schmid PC, Krebsbach RJ, Perry SR, Dettmer TM, Maasson JL, Schmid HHO (1995) Occurrence and postmortem generation of anandamide and other long-chain $\mathrm{N}$-acylethanolamines in mammalian brain. FEBS Lett 375:117-120.

Schmid PC, Schwartz KD, Smith CN, Krebsbach RJ, Berdyshev EV, Schmid HHO (2000) A sensitive endocannabinoid assay. The simultaneous analysis of $\mathrm{N}$-acylethanolamines and 2-monoacylglycerols. Chem Phys Lipids 104:185-191.

Shen M, Piser TM, Seybold VS, Thayer SA (1996) Cannabinoid receptor agonists inhibit glutamatergic synaptic transmission in rat hippocampal cultures. J Neurosci 16:4322-4334. 
Slipetz DM, O’Neill GP, Favreau L, Dufresne C, Gallant M, Gareau Y, Guay D, Labelle M, Metters KM (1995) Activation of the human peripheral cannabinoid receptor results in inhibition of adenylyl cyclase. Mol Pharmacol 48:352-361.

Smart D, Jonsson K-O, Vandervoorde S, Lambert DM, Fowler CJ (2002) "Entourage" effect of $\mathrm{N}$-acyl ethanolamines at human vanilloid receptor. Comparison of effects upon anandamide-induced vanilloid receptor activation and upon anandamide metabolism. $\mathrm{Br} \mathrm{J}$ Pharmacol 136:452-458.

Song Z-H, Zhong M (2000) CB1 cannabinoid receptor-mediated cell migration. J Pharmacol Exp Ther 294:204-209.

Stefano GB, Liu Y, Goligorsky MS (1996) Cannabinoid receptors are coupled to nitric oxide release in invertebrate immunocytes, microglia, and human monocytes. J Biol Chem 271:19238-19242.

Stella N, Piomelli D (2001) Receptor-dependent formation of endogenous cannabinoids in cortical neurons. Eur J Pharmacol 425:189-196.

Stella N, Schweitzer P, Piomelli D (1997) A second endogenous cannabinoid that modulates long-term potentiation. Nature 388:773-778.

Stence N, Waite M, Dailey ME (2001) Dynamics of microglial activation. Glia 33:256-266.

Stoll G, Jander S, Schroeter M (1998) Inflammation and glial responses in ischemic brain lesions. Prog Neurobiol 56:149-171.

Sugiura T, Kondo S, Sukagawa A, Tonegawa T, Nakane S, Yamashita A, Ishima Y, Waku K (1996) Transacylase-mediated and phosphodiesterase-mediated synthesis of $\mathrm{N}$-arachidonoylethanolamine, an endogenous cannabinoidreceptor ligand, in rat brain microsomes. Eur J Biochem 240:53-62.

Sugiura T, Kondo S, Kishimoto S, Miyashita T, Nakane S, Kodaka T, Suhara Y, Takayama H, Waku K (2000) Evidence that 2-arachidonylglycerol but not $N$-palmitoylethanolamine or anandamide is the physiological ligand for the cannabinoid CB2 receptor. Comparison of the agonistic activities of various cannabinoid receptor ligands in HL-60 cells. J Biol Chem 275:605-612.
Sugiura T, Yoshinaga N, Waku K (2001) Rapid generation of 2 -arachidonoylglycerol, an endogenous cannabinoid receptor ligand, in rat brain after decapitation. Neurosci Lett 297:175-178.

Tan AS, Berridge MV (2000) Superoxide produced by activated neutrophils efficiently reduces the tetrazolium salt, WST-1 to produce a soluble formazan: a simple colorimetric assay for measuring respiratory burst activation and for screening anti-inflammatory agents. J Immunol Methods 238:59-68.

Vogel Z, Barg J, Levy R, Saya D, Heldman E, Mechoulam R (1993) Anandamide, a brain endogenous compound, interacts specifically with the cannabinoid receptors and inhibits adenylate cyclase. J Neurochem 61:352-355.

Waksman Y, Olson JM, Carlisle SJ, Cabral GY (1999) The central cannabinoid receptor (CB1) mediates inhibition of nitric oxide production by rat microglial cells. J Pharmacol Exp Ther 288:1357-1366.

Walter L, Franklin A, Witting A, Möller T, Stella N (2002) Astrocytes in culture produce anandamide and other acylethanolamides. J Biol Chem 277:20869-20876.

Walter L, Franklin A, Witting A, Wade C, Xie Y, Kunos G, Mackie K, Stella N (2003) Non-psychotropic cannabinoid receptors regulate microglial cell migration. J Neurosci 23:1398-1405.

Wilkinson PC (1998) Assays of leucocyte locomotion and chemotaxis. J Immunol Methods 216:139-153.

Witting A, Müller P, Herrmann A, Kettenmann H, Nolte C (2000) Phagocytic clearance of apoptotic neurons by microglia/brain macrophages in vitro: involvement of lectin-, integrin-, and phosphatidylserine-mediated recognition. J Neurochem 75:1060-1070.

Yrjänheikki J, Tikka T, Keinänen R, Goldsteins G, Chan PH, Koistinaho J (1999) A tetracyclic derivative, minocycline, reduces inflammation and protects against focal cerebral ischemia with a wide therapeutic window. Proc Natl Acad Sci USA 96:13496-13500. 